\title{
Analysis of correlation between transcription activity of estrogen-dependent genes of cytochrome P450 and profile of estrogen receptor in endometrial adenocarcinoma
}

\author{
Analiza zależności pomiędzy aktywnością transkrypcyjną estrogenozależnych \\ genów cytochromu $\mathrm{P} 450$ a profilem receptorów estrogenowych \\ w gruczolakoraku endometrium \\ Agnieszka Jęda-Golonka1 (iD , Andrzej Witek ${ }^{1}$ (D) , Monika Paul-Samojedny² (iD), Celina Kruszniewska-Rajs² (iD) \\ 'Department of Gynaecological and Obstetrics, Faculty of Medical Sciences in Katowice, \\ Medical University of Silesia, Katowice, Poland \\ 2Department of Medical Genetics, Faculty of Pharmacentical Sciences in Sosnowiec, \\ Medical University of Silesia, Katowice, Poland
}

\begin{abstract}
INTRODUCTION: Studies show that the development of endometrial cancer is associated with the activity of estrogen-dependent genes, whose action is conditioned by the presence of estrogen receptors (ER). Analysis of the transcriptional activity of the genes which code ERs as well as the concentration profile of their isoforms could help to understand the mechanism of estrogen activity on the risk of endometrial cancer occurrence, as well as the mechanisms involved in its development and spread. The aim of the conducted studies was to compare the transcriptional activity of the genes coding ER-alpha and ER-beta estrogen receptors, determine the types of post-transcription modifications of ER mRNA in endometrial adenocarcinoma and normal endometrium as well as determine the transcriptome of estrogen-dependent genes of cytochrome P450.

MATERIAL AND METHODS: Extraction of the total RNA from 47 endometrium samples was performed with the TRIzol reagent (Invitrogen). The expression profile of the estrogen-dependent genes of cytochrome P450 was determined using the HG-U133A (Affymetrix) oligonucleotide microarray technique from among 22,283 IDs of mRNA IDs. The QRT-PCR reaction for quantification of the mRNA of estrogen receptors was performed using an ABI PRISMTM 7700 (TaqMan) sequence detector. For the QRT-PCR reaction, oligonucleotide starter sequences to detect the ER-alpha and ER-beta mRNA isoforms were designed using Primer ExpressTM Version 1.0 software.

RESULTS: In the presented work, it was found that estrogen receptor gene expression occurs in normal endometrium as well as in endometrial adenocarcinoma, and the dominating type is ER-alpha. The transcriptional activity of the ER-alpha and ER-beta genes decreases in adenocarcinoma with a simultaneous increase in the transcriptional activity ratio. The ER-alpha/delta5 isoform dominates in endometrial cancer. Statistical analysis conducted in the GeneSpring 11.5 programme showed that from the group of 91 mRNA IDs of the genes of cytochrome P450, 5 mRNA IDs differentiate, for $\mathrm{p}<0.5$ and $\mathrm{FC}(\log 2)>1.5$. In the presented work, it was found that the expression of estrogen receptor genes occurs in normal endometrium and endometrial adenocarcinoma, and the dominant type is ER-alpha. The transcriptional
\end{abstract}

\begin{tabular}{|c|c|c|}
\hline Received: 15.12 .2016 & Revised: 22.06 .2017 & Published online: 24.02 .2020 \\
\hline
\end{tabular}

Address for correspondence: Dr n. med. Agnieszka Jęda-Golonka, Katedra i Klinika Ginekologii i Położnictwa, Wydział Nauk Medycznych w Katowicach, Śląski Uniwersytet Medyczny w Katowicach, ul. Medyków 14, 40-752 Katowice, Polska, tel. + 483278947 31, e-mail: endometria.ligota@gmail.com

Copyright $\odot$ Śląski Uniwersytet Medyczny w Katowicach

www.annales.sum.edu.pl 
activity of the ER-alpha and ER-beta genes decreases in adenocarcinoma, while the transcriptional activity index increases. In endometrial cancer, the ER-alpha/delta5 isoform dominates. Statistical analysis conducted in GeneSpring 11.5 showed that from the group 91 ID mRNA of cytochrome P450 genes, 5 ID mRNA is differentiating, for $\mathrm{p}<0.5$ and FC $(\log 2)>1.5$.

CONCLUSIONS: The presence of such a transcriptional profile of the studied genes in endometrial adenocarcinoma may indicate that post-transcriptional modifications of estrogen receptors are associated with changes triggering carcinogenesis.

\section{KEY WORDS}

endometrial cancer, estrogen receptors, estrogen-dependent genes, cytochrome P450, oligonucleotide microarray, posttranscription modifications

\section{STRESZCZENIE}

WSTĘP: Badania wskazują, że wzrost raka endometrium ma związek z aktywnością genów estrogenozależnych, których działanie jest uwarunkowane obecnością receptorów estrogenowych (ER). Analiza aktywności transkrypcyjnej genów kodujących ERs oraz profilu stężeń ich izoform mogłaby pomóc w zrozumieniu mechanizmów wpływu estrogenów na ryzyko wystąpienia raka endometrium, a także mechanizmów zaangażowanych w jego rozwój i rozprzestrzenianie. Celem prowadzonych badań było porównanie aktywności transkrypcyjnej genów kodujących receptory estrogenowe ER-alfa i ER-beta, wyznaczenie typów modyfikacji potranskrypcyjnych mRNA ERs w gruczolakoraku endometrium i endometrium prawidłowym oraz wyznaczenie transkryptomu estrogenozależnych genów cytochromu P450.

MATERIAŁ I METODY: Ekstrakcję całkowitego RNA z 47 próbek endometrium przeprowadzono przy użyciu odczynnika TRIzol (Invitrogen). Techniką mikromacierzy oligonukleotydowych HG-U133A (Affymetrix) spośród 22283 ID mRNA wyznaczono profil ekspresji estrogenozależnych genów cytochromu P450. Reakcję QRT-PCR w celu oznaczenia ilościowego mRNA receptorów estrogenowych wykonano z zastosowaniem detektora sekwencji ABI PRISMTM 7700 (TaqMan). Do reakcji QRT-PCR zaprojektowano sekwencje oligonukleotydowych starterów do detekcji izoform mRNA ER-alfa i ER-beta, wykorzystując program komputerowy Primer ExpressTM Version 1.0.

WYNIKI: W przedstawionej pracy stwierdzono, że ekspresja genów receptorów estrogenowych występuje w endometrium prawidłowym oraz gruczolakoraku endometrium, a dominującym typem jest ER-alfa. Aktywność transkrypcyjna genów ER-alfa i ER-beta zmniejsza się w gruczolakoraku, przy równoczesnym wzroście wskaźnika aktywności transkrypcyjnej. W raku endometrium dominuje izoforma ER-alfa/delta5. Analiza statystyczna przeprowadzona w programie GeneSpring 11.5 wykazała, że z grupy 91 ID mRNA genów cytochromu P450 różnicujących jest 5 ID mRNA, dla $\mathrm{p}<0,5$ i FC $(\log 2)>1,5$.

WNIOSKI: Obecność takiego profilu transkrypcyjnego badanych genów w gruczolakoraku endometrium może wskazywać na związek modyfikacji potranskrypcyjnych receptorów estrogenowych ze zmianami uruchamiającymi karcinogenezę.

\section{SŁOWA KLUCZOWE}

rak endometrium, receptory estrogenowe, estrogenozależne geny, Cytochrom P450, mikromacierz oligonukleotydowa, modyfikacje potranskrypcyjne

\section{INTRODUCTION}

There has been significant progress in cancer diagnostics and treatment in recent years. In this regard, the indication of the role of estrogen receptors in the transmission of intracellular signals regulating gene expression in estrogen-dependent tissues was an important achievement. These mechanisms can be disrupted in the course of many cancers, which consequently leads to the initiation of neoplastic transformation.

Endometrial cancer is one of the most common cancers in women, which makes it a significant problem, both oncological and social. The incidence of this type of cancer has been steadily growing in recent years. Currently, endometrial cancer is the fourth most frequently occurring cancer in Poland, after breast, lung and skin cancer. In 19801,827 new cases were reported and the

\section{WSTĘP}

W ostatnich latach nastąpił znaczny postęp w diagnostyce terapii nowotworów. Ważnym osiągnięciem w tym zakresie było wskazanie na rolę receptorów estrogenowych w przekazywaniu wewnątrzkomórkowych sygnałów regulujących ekspresję genów w tkankach estrogenozależnych. W przebiegu wielu nowotworów może dochodzić do zakłócenia tych mechanizmów, co w konsekwencji prowadzi do zapoczątkowania transformacji nowotworowej.

Rak endometrium należy do najczęstszych nowotworów złośliwych u kobiet, stając się istotnym problemem zarówno onkologicznym, jak i społecznym. Częstość zachorowań na ten typ nowotworu w ciągu ostatnich lat systematycznie rośnie. Aktualnie zajmuje on w Polsce czwarte miejsce pod względem częstości występowania 
standardized incidence rate was 7.9, while in 2013 those numbers were, respectively, 5,706 and 16.6 [1].

The disease rarely occurs before the age of 40 . The highest incidence is observed in the age group 55-64 [2]. Since the number of women over the age of 60 is growing in our society, it should be expected that as the population at risk increases, the number of those who develop this type of cancer should also increase.

Endometrioid carcinoma, that is endometrial adenocarcinoma associated with estrogen stimulation, is the most common type among endometrial cancers. Women with higher socio-economic status are more likely to develop this type of cancer. Moreover, it has been observed that the incidence of endometrial cancer increases with the level of industrialization of a given region, which testifies to the strong influence of environmental factors [3]. The role of estrogens as an important factor in endometrial cancer etiology has been known for years. Depending on the time of their use, the risk increases from $20 \%$ after one year to $62 \%$ after 3 years. The highest risk is found in women using estrogens for 10 or more years [4]. lower risk is observed in slim women who do not suffer from diabetes and have normal blood pressure.

The regulation of neoplastic growth by estrogens results from their regulatory functions in estrogen-dependent tissues, and may depend significantly on the profile of estrogen receptor concentrations [5]. Two estrogen receptor subtypes are currently known: ER-alpha and ER-beta, coded by genes composed of eight exons and seven introns, and located on two different chromosomes: ER-alpha: 6q24-27 (NR 3A1); ER-beta: 14q2224 (NR 3A2). Human ER-beta is highly homologous with ER-alpha and the highest degree of homology $(96 \%)$ is shown by the domain responsible for binding with DNA. Structurally, estrogen receptors consist of regions marked from to $\mathrm{F}$. In terms of their function, the domains responsible for transcription transactivation (domains AF-1 and AF2), receptor translocation to the cellular nucleus (NLS domain), ligand attachment (LBD domain) and binding with DNA (DBD domain) are distinguished. The domain responsible for binding the receptor-steroid complex to DNA (DNA binding domain) has a double zinc finger structure, which enables the complex to recognize the place on chromatin and bind to nuclear DNA after activating the receptor [6]. Estrogen receptors are transcription factors which can stimulate (positive regulation) or inhibit (negative regulation) gene expression. Signal transduction via estrogen receptors is conditioned by their structure, therefore changes in their receptor structure may, weaken, prevent or intensify the effect of estrogen on gene transcription. The variety of ascertained forms of alpha or beta estrogen receptor mRNA in estrogen-dependent tissues is a result of alternative splicing, in which the primary transcript (pre-mRNA) can undergo various types of post-transcriptional processing (gene cutting and splicing as well as modifications of the 5' and $3^{\prime}$ ends), but also post-transcriptional modifications, which change the sense of the transcripts ( $m R N A$ editing). Alter- nowotworów złośliwych wśród kobiet, po raku sutka, płuc i skóry. W roku 1980 zarejestrowano 1827 nowych zachorowań, a standaryzowany współczynnik zachorowalności wynosił 7,9, natomiast 2013 roku liczby te przedstawiały się odpowiednio: 5706 i 15,6 [1].

Choroba ta rzadko pojawia się przed 40 r.ż., a największa zachorowalność występuje w wieku 55-64 lat [2]. W naszym społeczeństwie rośnie liczba kobiet, które przekroczyły 60 r.ż., należy zatem oczekiwać wraz ze wzrostem liczebności populacji będącej w grupie ryzyka, zwiększenia liczby tych, które zachorują na ten typ nowotworu.

Wśród raków endometrium najczęstszy jest rak endometrioidalny, czyli gruczolakorak endometrium związany ze stymulacją estrogenową. Kobiety o wyższym statusie socjoekonomicznym są bardziej narażone na zachorowanie. Ponadto zaobserwowano, że częstość raka endometrium rośnie wraz ze stopniem industrializacji danego regionu, co świadczy o silnym wpływie czynników środowiskowych [3].

Rola estrogenów, jako znaczącego czynnika etiologii raka endometrium, jest znana od wielu lat. W zależności od czasu ich stosowania, ryzyko to wzrasta od $20 \%$ po roku do $62 \%$ po trzech latach. Najwyższe ryzyko stwierdza się w grupie kobiet stosujących estrogeny przez 10 lub więcej lat [4]. Mniejsze ryzyko obserwuje się u szczupłych kobiet, niechorujących na cukrzycę i z prawidłowym ciśnieniem krwi.

Regulacja wzrostu nowotworowego przez estrogeny wynika z ich funkcji regulacyjnych w estrogenozależnych tkankach może zależeć istotnie od profilu stężeń receptorów estrogenowych [5]. Obecnie znane są dwa subtypy receptora estrogenowego: ER-alfa ER-beta, kodowane przez geny zbudowane z ośmiu eksonów i siedmiu intronów, a zlokalizowane na dwóch różnych chromosomach: ER-alfa: 6q24-27 (NR 3A1); ER-beta: 14q22-24 (NR 3A2). Ludzki ER-beta jest wysoce homologiczny z ER-alfa, przy czym najwyższy stopień homologii (96\%) wykazuje domena odpowiedzialna za wiązanie z DNA. Pod względem strukturalnym receptory estrogenowe składają się $\mathrm{z}$ regionów oznaczonych kolejno literami od A do F. Pod względem funkcjonalnym wyróżnia się domeny odpowiedzialne za transaktywację transkrypcji (domeny AF-1 i AF-2), translokację receptora do jadra komórkowego (domena NLS), przyłączanie liganda (domena LBD) i wiązanie z DNA (domena DBD). Domena odpowiedzialna za wiązanie kompleksu receptor-steroid z DNA (DNA binding domain) posiada strukturę podwójnego palca cynkowego, która po zaktywowaniu receptora umożliwia kompleksowi rozpoznanie miejsca na chromatynie i związanie z jądrowym DNA [6].

Receptory estrogenowe są czynnikami transkrypcyjnymi mogącymi pobudzać (regulacja pozytywna) lub hamować (regulacja negatywna) ekspresję genów. Przekazywanie sygnału za pośrednictwem receptorów estrogenowych jest uwarunkowane ich strukturą, dlatego zmiany w ich budowie receptora mogą osłabiać, uniemożliwić lub nasilać oddziaływanie estrogenu na transkrypcję genów. Różnorodność stwierdzanych 
native splicing of mRNA is without a doubt one of the mechanisms which control he ER activity [7].

In terms of function, the variants of post-transcriptional modifications of ER mRNA can be divided into two categories. The first one comprises positively dominating receptors showing activity even in the absence of ligand, thus being able to enable the cancer tissue to become independent from hormonal regulation and acquire resistance to hormone therapy, for example ER-alpha/delta5). The second group includes negatively dominating receptors, which have no ability of transactivation and block the activity of the normal form of the receptor (e.g. ER-alpha/delta3 and ER-alpha/delta7) [8]. From the clinical point of view, it is important how the regulatory sequence of ERE, the ability to bind ligands, translocation to the cellular nucleus, binding to DNA and the creation of complexes with other transcription factors and, as result the activation of estrogen-dependent gene transcription, change.

In recent years, progress has been made in the isolation and characterization of genes coding the isoenzymes of cytochrome P450, indicating the significant role of their expression at the transcription stage with the involvement of transcription factor, such as an estrogen receptor $[9,10]$. Cytochromes P450 are large and multi-functional superfamily of enzymatic proteins showing the activity of monoamine oxidases involved in the metabolism of endogenous compounds and steroid hormones, the metabolism of fatty acids and their derivatives, as well as the activation or deactivation of drugs and the metabolism of other foreign compounds entering the organism. Moreover, there are many substances which undergo biotransformation into reactive transitional forms with the involvement of cytochrome P450, which determines or intensifies their mutagenic or carcinogenic activity, leading to cell dysfunction and, as result, carcinogenesis [11].

Knowledge of the molecular mechanisms which underlie the basis of the changes occurring in the endometrium is still insufficient. The pleiotropicity of ER is strictly associated with their transcriptional activity, post-transcriptional modifications of ER mRNA and the type of formation of ER homo- and heterodimers responsible for gene expression regulation. Changes in the ER-alpha and ER-beta relationship may also be related to carcinogenesis. High hopes in the diagnostics, therapy and prognosis of the course of the disease are placed in the search for correlations between the expression of estrogen-dependent genes and the stage of endometrial cancer, as well as between the concentration profile of estrogen receptor isoforms and changes in the expression of estrogen-dependent genes. These studies may contribute to increasing the accuracy of diagnoses and influence the therapeutic approach.

\section{AIM OF THE STUDY}

The aim of the study is to assess the transcriptional activity of estrogen receptors, types of ER post-transcrip- form mRNA receptora estrogenowego alfa lub beta w estrogenozależnych tkankach jest wynikiem alternatywnego składania, w którym pierwotny transkrypt (pre-mRNA) może ulegać różnego rodzaju obróbkom potranskrypcyjnym (cięcie i składanie genowe oraz modyfikacje końców 5' 3'), lecz także skutkiem zmian potranskrypcyjnych zmieniających sens transkryptów, tzw. redagowanie mRNA (ending). Alternatywne składanie mRNA jest niewątpliwie jednym z mechanizmów kontrolujących aktywność ER [7].

Pod względem funkcjonalnym warianty modyfikacji potranskrypcyjnych mRNA ERs można podzielić na dwie kategorie. Pierwsza obejmuje dominujące pozytywnie receptory wykazujące aktywność nawet przy nieobecności liganda, a więc mogące umożliwić tkance nowotworowej uzyskanie niezależności od regulacji hormonalnej i nabycie oporności na hormonoterapię, np. ER-alfa/delta5. Druga grupa to dominujące negatywnie receptory, które nie mają zdolności transaktywacji i blokują aktywność prawidłowej formy receptora (np. ER-alfa/delta3 i ER-alfa/delta7) [8]. Z klinicznego punktu widzenia ważne jest, jak zmienia się sekwencja regulatorowa ERE, zdolność wiązania ligandów, translokacja do jądra komórkowego, wiązanie DNA i tworzenia kompleksów z innymi czynnikami transkrypcyjnymi, a w efekcie aktywowanie transkrypcji estrogenozależnych genów.

W ostatnich latach dokonał się postęp w izolacji i charakterystyce genów kodujących izoenzymy cytochromu P450, wskazując na istotną rolę kontroli ich ekspresji na etapie transkrypcji przy udziale czynnika transkrypcyjnego, takiego jak receptor estrogenowy $[9,10]$. Cytochromy P450 to liczna wielofunkcyjna nadrodzina białek enzymatycznych wykazujących aktywność monooksydaz, zaangażowane w metabolizm związków endogennych i hormonów steroidowych oraz metabolizm kwasów tłuszczowych i ich pochodnych, a także aktywację lub inaktywację leków i metabolizm innych związków obcych dostających się do organizmu. Ponadto jest wiele substancji, które ulegają biotransformacji przy udziale cytochromu P450 do reaktywnych form przejściowych, co determinuje lub nasila ich mutagenne bądź rakotwórcze działanie, prowadząc do dysfunkcji komórki, a w konsekwencji do kancerogenezy [11].

Wiedza na temat molekularnych mechanizmów leżących u podstaw przemian zachodzących endometrium jest wciąż niewystarczająca. Plejotropowowść ER ściśle wiąże się $\mathrm{z}$ ich aktywnością transkrypcyjną, modyfikacjami potranskrypcyjnymi mRNA ER i typem tworzenia homo- i heterodimerów ER odpowiedzialnych za regulację ekspresji genów [12]. Także zmiany w stosunku ER-alfa do ER-beta mogą być związane $\mathrm{z}$ kancerogenezą. Duże nadzieje w diagnostyce, terapii i prognozowaniu przebiegu choroby pokłada się w poszukiwaniu zależności pomiędzy ekspresją genów estrogenozależnych a stopniem zaawansowania raka endometrium oraz profilem stężeń izoform receptorów estrogenowych a zmianą ekspresji genów estrogenozależnych. Badania te mogą przyczynić się do zwiększe- 
tional modifications and to determine the transcriptome of estrogen-dependent genes of cytochrome P450 in the tissue of endometrioid cancer of the body of the uterus as well as to attempt to determine a correlation between the concentration profile of estrogen receptor isoforms and changes in the expression of estrogen-dependent genes.

The process of acheiving the aim of the study consisted of the following stages:

1. Determining 22,283 mRNA ID transcriptome of endometrium specimens by the oligonucleotide microarray technique and identifying the mRNA ID associated with the activity of estrogen-dependent genes of cytochrome $\mathrm{P} 450$ differentiating endometrial adenocarcinoma from the reference group.

2. Determining the transcription activity of ER-alpha and ER-beta genes by the QTR-PCR technique and searching for correlations between the transcriptional activity of ER-alpha and ER-beta genes in normal endometrium and endometrial adenocarcinoma.

3. Determining the types of alternative splicing of ER-alpha and ER-beta mRNA using designed starters and determining the ratio of the proportion of ER-alpha and ER-beta mRNA variants in the total pool of estrogen receptors.

\section{MATERIAL AND METHODS}

The analysis included forty-seven women hospitalized in the Department and Clinic of Gynecology and Obstetrics at the Medical University of Silesia in Katowice, in whom the body of the uterus had been removed due to such indications as: endometrial cancer, uterine fibroids, tumors of uterine appendages and uterine prolapse. The pathomorphological inclusion criteria included: endometrium in the proliferative phase $(n=24)$ and endometrioid endometrial adenocarcinoma (EEC - endometroid endometrial cancer) of various histopathological grades $(\mathrm{G} 1=7, \mathrm{G} 2=11, \mathrm{G} 3=5)$. In the group of women with endometrium in the proliferative phase, the mean BMI value was within the norm and was equal to $24.2 \mathrm{~kg} / \mathrm{m}^{2}( \pm 2.4)$. In the case of diagnosed adenocarcinoma, only one woman had BMI within the normal limits. The mean BMI value for the group was $30.4 \mathrm{~kg} / \mathrm{m}^{2}( \pm=5.6)$. All the women with endometrial cancer included in the study were in the first or second stage of clinical advancement according to FIGO, in which the cancer had not spread beyond the uterus. The exclusion criteria were: hormone therapy within 12 months prior to the procedure, diagnosed endometriosis and non-endometrioid endometrial cancer. Consent for determining gene expression in the studied material was given by the Bioethics Committee of the Medical University of Silesia in Katowice (KNW/0022/ KB1/98/12).

The material for the study was collected in the operating room, immediately after uterus removal. Frontal dissection of the uterine body, from the external ori- nia dokładności rozpoznań oraz wpływać na postępowanie terapeutyczne.

\section{CEL PRACY}

Celem pracy jest ocena aktywności transkrypcyjnej receptorów estrogenowych, typów modyfikacji potranskrypcyjnych ER i wyznaczenie transkryptomu estrogenozależnych genów cytochromu P450 w tkance raka endometrioidalnego trzonu macicy oraz próba określenia zależności pomiędzy profilem stężeń izoform receptorów estrogenowych i zmianą ekspresji estrogenozależnych genów.

Realizacja celu pracy obejmowała następujące etapy:

1. Wyznaczenie transkryptomu 22283 ID mRNA wycinków endometrium techniką mikromacierzy oligonukleotydowych oraz wytypowanie ID mRNA związanych z aktywnością estrogenozależych genów cytochromu P450 różnicujących gruczolakoraka endometrium od grupy referencyjnej.

2. Wyznaczenie aktywności transkrypcyjnej genów ER-alfa ER-beta techniką QRT-PCR oraz poszukiwanie zależności pomiędzy ich aktywnością transkrypcyjną $\mathrm{w}$ endometrium prawidłowym i gruczolakoraku endometrium.

3. Wyznaczenie typów alternatywnego składania mRNA ER-alfa i ER-beta z zastosowaniem zaprojektowanych starterów oraz wyznaczenie wskaźnika udziału wariantów mRNA ER-alfa i ER-beta w całkowitej puli receptorów estrogenowych.

\section{MATERIA METODY}

Analizie poddano 47 kobiet hospitalizowanych w Katedrze i Klinice Ginekologii i Położnictwa Śląskiego Uniwersytetu Medycznego Katowicach, u których wykonano usunięcie trzonu macicy, ze względu na takie wskazania, jak: rak trzonu macicy, mięśniaki macicy, guzy przydatków macicy oraz wypadanie narządu rodnego. Patomorfologiczne kryteria włączenia stanowiły: endometrium $\mathrm{w}$ fazie proliferacyjnej $(\mathrm{n}=24)$ i gruczolakorak endometrium typu endometrioidalnego (endometroid endometrial cancer - EEC) w różnym stopniu zróżnicowania histopatologicznego $(\mathrm{G} 1=7, \mathrm{G} 2=11$, $\mathrm{G} 3=5$ ). $\mathrm{W}$ grupie kobiet $\mathrm{z}$ endometrium $\mathrm{w}$ fazie wzrostowej średnia wartość BMI mieściła się $\mathrm{w}$ granicach normy i wynosiła $24,2 \mathrm{~kg} / \mathrm{m}^{2}( \pm 2,4)$. W przypadku rozpoznanego gruczolakoraka tylko u jednej chorej BMI był w granicach normy, a średnia wartość BMI dla tej grupy wynosiła $30,4 \mathrm{~kg} / \mathrm{m}^{2}( \pm=5,6)$. Wszystkie kobiety $\mathrm{z}$ rakiem endometrium objęte badaniem znajdowały się w I i II stopniu klinicznego zaawansowania wg FIGO, w którym nowotwór nie wychodził poza macicę. Kryteria wykluczenia obejmowały: stosowanie terapii hormonalnej 12 miesięcy przez zabiegiem, rozpoznana endometrioza i rak endometrium typu nieendometrioidalnego. Zgodę na oznaczenie ekspresji genów w bada- 
fice of the cervical canal to the fundus uteri, made it possible to view the uterine cavity and to take a tissue fragment from the endometrium using biopsy forceps. The endometrium samples were placed in sterile tubes containing RNAlater ${ }^{\mathrm{TM}}$ (Sigma) in the amount of $10 \mu \mathrm{l}$ per $1 \mathrm{mg}$ of tissue $\left(200 \mu \mathrm{l}\right.$ RNAlater ${ }^{\mathrm{TM}}$ per $20 \mathrm{mg}$ of tissue) and sent to the Department and Faculty of Molecular Biology in Sosnowiec, where they were stored at $-80^{\circ}$ until the next stage of molecular analysis.

Extraction of RNA from the tissue material was conducted using a TRIzol ${ }^{\mathrm{TM}}$ reagent set (Invitrogen Life Technologies, California, USA). Then, the extract was purified by etching with DNAase I (deoxyribonuclease I) on the columns of an RNeasy Mini Kit set (Qiagen, Valencia, CA). Qualitative assessment of the extracts was conducted by agarose electrophoresis, and the quantitative assessment by means of Gene Quant spectrophotometer (Pharmacia Biotech, Cambridge, UK).

The transcriptome consisting of 22,283 mRNA were determined by the HG-U133A oligonucleotide microarray technique (Affymetrix, Santa Clara, CA) in accordance with the recommendations contained in the Affymetrix Gene Expression Analysis Technical Manual. The analysis began with cDNA synthesis on the array of the obtained ribonucleic acid extract using an Invitrogen SuperScript Choice System set (Gibco BRL SuperScript Life Technologies). Double-stranded ds-cDNA was the array for the synthesis of biotinylated cRNA using a BioArray HighYield RNA Transcript Labeling Kit (Enzo Life Science, NY). cRNA labelled with biotin was purified on the RNeasy Mini Kit columns (Qiagen, Gmbh, Hilden Germany), subjected to fragmentation and hybridization with a Human Genome Arrays HG-U133A microarray (Affymetrix, Santa Clara, CA). cRNA hybridized with the microarray was subjected to labelling with the streptavidin-phycoerythrin complex. The intensity of the fluorescence signals on the plate corresponding to 22,283 mRNA IDs was read using GeneArray Scaner G2500A (Agilent Technologies, CA).

After initial assessment of the array experiment quality in the Microarray Site 5 program (Affymetrix), normalization of the results was performed in the RMA Express program, which enabled their assessment and comparison of the concentration profiles of all the transcripts labelled on $47 \mathrm{HG}-\mathrm{U} 133 \mathrm{~A}$ microarrays. On the basis of the NetAffix ${ }^{\mathrm{TM}}$ database (Affymetrix) and the literature data, the numbers (so-called IDs) of the cytochrome P450 genes present on the HG-U133A plate were sought. Subsequently, on the basis of statistical analyses conducted by means of Gene Spring 11.5 software (Agilent Technologies, CA), differential genes were selected, assuming p-value $<0.05$ and FC parameter $\left(\log _{2}\right)>1.5$ as statistically significant results (fold change - indicating $\log _{2}$ for a multiple fluorescence signal difference between the tested and control transcripts). Quantitative analysis of estrogen receptor mRNA was conducted employing specific starters for particular variants of post-transcriptional mRNA modifications. In the presented studies, the QRT-PCR reaction was per- nym materiale wydała Komisja Bioetyczna Śląskiego Uniwersytetu Medycznego w Katowicach (KNW/0022/ KB1/98/12).

Materiał do badania pobrano na sali operacyjnej bezpośrednio po usunięciu macicy. Rozcięcie trzonu macicy w linii czołowej, od ujścia zewnętrznego kanału szyjki macicy do dna, umożliwiło uwidocznienie jamy macicy i pobranie fragmentu tkankowego $\mathrm{z}$ endometrium przy użyciu kleszczyków biopsyjnych. Próbka endometrium została umieszczona w sterylnych probówkach zawierających RNAlater $^{\mathrm{TM}}$ (Sigma) w ilości $10 \mu \mathrm{l}$ na $1 \mathrm{mg}$ tkanki $\left(200 \mu \mathrm{l}\right.$ RNAlater ${ }^{\mathrm{TM}}$ na $20 \mathrm{mg}$ tkanki) i przekazana do Katedry i Zakładu Biologii Molekularnej w Sosnowcu, gdzie w temperaturze $-80^{\circ}$ była przechowywana do czasu kolejnego etapu analizy molekularnej.

Ekstrakcję RNA z materiału tkankowego przeprowadzono przy użyciu zestawu odczynników TRIzol ${ }^{\mathrm{TM}}$ (Invitrogen Life Technologies, Kalifornia, USA). Następnie ekstrakt oczyszczono przez trawienie DNA-zą I (deoksyrybonukleazą I) na kolumnach zestawu RNeasy Mini Kit (Qiagen, Valencia, CA). Ocenę jakościową ekstraktów przeprowadzono metodą elektroforezy agarozowej, a ilościowo techniką spektrofotometrii przy użyciu spektrofotometru Gene Quant (Pharmacia Biotech, Cambridge, UK).

Traskryptom złożony z 22283 mRNA wyznaczono techniką mikromacierzy oligonukleotydowych HG-U133A (Affymetrix, Santa Clara, CA), zgodnie z zaleceniami zawartymi w Affymetrix Gene Expression Analysis Technical Manual. Analizę rozpoczęto od syntezy cDNA na matrycy otrzymanego ekstraktu kwasu rybonukleinowego przy użyciu zestawu Invitrogen SuperScript Choice System (Gibco BRL SuperScript Life Technologies). Dwuniciowy ds cDNA stanowił matrycę do syntezy biotynylowanego cRNA z zastosowaniem zestawu BioArray HighYield RNA Transcript Labeling Kit (Enzo Life Science, NY). Znakowany biotyną cRNA oczyszczono na kolumnach RNeasy Mini Kit (Qiagen, Gmbh, Hilden Germany), poddano fragmentacji i hybrydyzacji z mikromacierzą Human Genome Arrays HG-U133A (Affymetrix, Santa Clara, CA). Zhybrydyzowany $\mathrm{z}$ mikromacierzą cRNA poddano znakowaniu kompleksem streptowidyna-fikoerytryna. Intensywność sygnałów fluorescencji na płytce odpowiadającą 22283 ID mRNA odczytano przy użyciu skanera GeneArray Scaner G2500A (Agilent Technologies, CA).

Po wstępnej ocenie jakości eksperymentu macierzowego w programie Microarray Site 5 (Affymetrix) przeprowadzono normalizację wyników w programie RMA Express, umożliwiającym ich ocenę i porównanie profilu stężeń wszystkich transkryptów oznaczonych na 47 mikromacierzach HG-U133A. Na podstawie bazy danych NetAffix ${ }^{\mathrm{TM}}$ firmy Affymetrix oraz danych literaturowych wyszukano numery (tzw. ID) genów cytochromu P450 obecne na płytce HG-U133A. Następnie na podstawie analiz statystycznych przeprowadzonych przy użyciu programu Gene Spring 11.5 (Agilent Tech- 
formed in single step in $50 \mu \mathrm{l}$ of solution containing 1xTaqMan buffer A with fluorochrome, which provided a suitable background for fluorescence measurements after each thermal cycle of the ORT-PCR reaction. The number of mRNA molecules of the studied genes (ER-alpha and ER-beta) was determined on the basis of the kinetics of the QRT-PCR reaction using an ABI PRISM $^{\mathrm{TM}} 7700$ sequence detector (TaqMan). The sequences for oligonucleotide starters to detect ER-alpha and ER-beta mRNA were designed by means of the Primer Express ${ }^{\mathrm{TM}}$ program, version 1.0, on the basis of the sequences of the studied genes from the GenBank database (http://ncbi.nlm.nih.gov) (Tab. I). Simultaneously, amplification of a commercially available fragment of the $\beta$-actin gene was performed in five different concentrations (from $1 \times 10^{3}$ do $2 \times 10^{4}$ ) and three repetitions nologies, CA) typowano geny różnicujące, przyjmując za statystycznie istotne wyniki charakteryzujące się wartością $\mathrm{p}<0,05$ oraz parametru FC $\left(\log _{2}\right)>1,5$ (fold change - wskazujący $\log _{2}$ wielokrotności różnicy sygnałów fluorescencji pomiędzy badanymi a kontrolnymi transkryptami).

Analizę ilościową mRNA receptorów estrogenowych przeprowadzono, stosując specyficzne startery dla poszczególnych wariantów modyfikacji potranskrypcyjnych mRNA. W przedstawionych badaniach reakcję QRT-PCR wykonywano jednostopniowo $50 \mu \mathrm{l}$ roztworu zawierającego $1 \mathrm{x}$ TaqMan bufor $\mathrm{A} \mathrm{z}$ fluorochromem, który zapewniał odpowiednie tło dla pomiaru fluorescencji po każdym cyklu termicznym reakcji ORT-PCR. Liczbę cząsteczek mRNA badanych genów (ER-alfa i ER-beta) wyznaczono na podstawie

Table I. Sequences of primers designed for ER-alpha and ER-beta Tabela I. Sekwencje zaprojektowanych starterów dla ER-alfa i ER-beta

\begin{tabular}{|c|c|c|c|c|}
\hline mRNA variant & Starter/probe & Nucleotide sequence & Location in mRNA & Amplimer \\
\hline \multirow{2}{*}{ ER-alfa } & FERaE1 & 5'accatgaccctccacaccaaagcatc3' & $364-389$ & \multirow{2}{*}{158 pz } \\
\hline & RERaE1 & 5'gtagttgtacacggcgggcttgctg 3' & $522-498$ & \\
\hline \multirow{2}{*}{ ER-alfa/delta2 } & FERaE1 & 5'accatgaccctccacaccaaagcatc3' & $364-389$ & \multirow{2}{*}{$461 \mathrm{pz}$} \\
\hline & ${ }^{*} \mathrm{RERaE} 1 / 3$ & $5^{\prime}$ tcgttatgtcctgtagaatgccggcg3' & $1013-1004 / 812-797$ & \\
\hline \multirow{3}{*}{ ER-alfa/delta2/3 } & FERaE1 & 5'accatgaccctccacaccaaagcatc3' & $364-389$ & \multirow{3}{*}{464 pz } \\
\hline & ${ }^{*} \mathrm{RERaE} 1 / 4$ & 5'tctttcgtatccctgtagaatgccggc3' & $1133-1121 / 812-798$ & \\
\hline & SERaE1 & 5'tcagatccaagggaacgagctggagcccct3' & $408-437$ & \\
\hline \multirow[t]{2}{*}{ ER-alfa/delta3 } & ${ }^{*} \mathrm{FERaE} 2 / 4$ & 5’tcaagggatacgaaaagaccgaagagga 3' & $1573-1595 / 1729-1737$ & \multirow{2}{*}{$451 \mathrm{pz}$} \\
\hline & $\mathrm{RERaE} 4 / 5$ & $5^{\prime}$ tccacaaagcctggcaccctcttc $3 '$ & $1466-1457 / 1456-1443$ & \\
\hline \multirow[t]{2}{*}{ ER-alfa/delta4 } & ${ }^{*} \mathrm{FERaE} 3 / 5$ & 5' gggaatgatgaaaggtggctttgtgg 3' & $1441-1456 / 1730-1601$ & \multirow{2}{*}{683 pz } \\
\hline & RERaE8 & $5^{\prime}$ tatgacctgctgctggagatgctgg $3^{\prime}$ & 1969-1993 & \\
\hline \multirow{2}{*}{ ER-alfa/delta5 } & *FERaE4/6 & 5' gcgaagagggtgccaggaacca 3' & $999-1004 / 1121-1143$ & \multirow{2}{*}{543 pz } \\
\hline & RERaE8 & $5^{\prime}$ tatgacctgctgctggagatgctgg $3^{\prime}$ & 1969-1993 & \\
\hline \multirow{2}{*}{ ER-alfa/delta6 } & *FERaE5/7 & 5' gctcctaacttgctcttggacaggagtgtac 3' & $1104-1120 / 1457-1465$ & \multirow{2}{*}{559 pz } \\
\hline & RERaE8 & $5^{\prime}$ tatgacctgctgctggagatgctgg $3^{\prime}$ & $1969-1993$ & \\
\hline \multirow{2}{*}{ ER-alfa/delta7 } & *FERaE6/8 & 5'cttaattctgtaacaaaggcatggagcatctg3' & $1720-1729 / 1914-1935$ & \multirow{2}{*}{218 pz } \\
\hline & RERaE8 & $5^{\prime}$ tatgacctgctgctggagatgctgg $3^{\prime}$ & $1969-1993$ & \\
\hline \multirow{2}{*}{ ER-beta1 } & $\mathrm{F} \llbracket 1$ & $5^{\prime}$ atgtaccctctggtcacagcgacc $3^{\prime}$ & $(1646-1669)$ & \multirow{2}{*}{$251 \mathrm{pz}$} \\
\hline & ${ }^{*} \mathrm{R} \square 1$ & 5' ctccagcagcaggtcatacactggga 3 ' & $(1872-1897)$ & \\
\hline \multirow{2}{*}{ ER-beta2 } & $\mathrm{F} \llbracket 1$ & $5^{\prime}$ atgtaccctctggtcacagcgacc $3^{\prime}$ & $(1646-1669)$ & \multirow{2}{*}{188 pz } \\
\hline & ${ }^{*} \mathrm{R} \llbracket 2$ & 5' cttttctgccctcgcatgcctga 3' & $(1811-1834)$ & \\
\hline \multirow{2}{*}{ ER-beta3 } & $\mathrm{F} \llbracket 1$ & $5^{\prime}$ atgtaccctctggtcacagcgacc $3^{\prime}$ & $(1698-1721)$ & \multirow{2}{*}{222 pz } \\
\hline & ${ }^{*} \mathrm{R} \llbracket 3$ & 5' ggcttccctcagcataaacaatctccaag 3' & $(1891-1919)$ & \\
\hline \multirow{2}{*}{ ER-beta4 } & $\mathrm{F} \llbracket 1$ & $5^{\prime}$ atgtaccctctggtcacagcgacc $3^{\prime}$ & $(1646-1669)$ & \multirow{2}{*}{209 pz } \\
\hline & ${ }^{*} \mathrm{R} \rrbracket 4$ & 5 ' tcaaatgaatgaattgcttttctccccat 3 ' & $(1814-1824 / 1825-1841)$ & \\
\hline \multirow{2}{*}{ ER-beta5 } & $\mathrm{F} \llbracket 1$ & $5^{\prime}$ atgtaccctctggtcacagcgacc $3^{\prime}$ & $(1646-1669)$ & \multirow{2}{*}{188 pz } \\
\hline & $\left.{ }^{*} \mathrm{R}\right] 5$ & 5'ggcgcgtacctcgcatgcct 3' & $(1814-1824 / 1825-1834)$ & \\
\hline \multirow{2}{*}{ ER-beta5/6 } & ${ }^{*} \mathrm{~F} \llbracket 5 / 6$ & $5^{\prime}$ tgggccaagaagattcccggtatgtac $3^{\prime}$ & $(762-788)$ & \multirow{2}{*}{$273 p z$} \\
\hline & R11 & 5' ctccagcagcaggtcatacactggga 3' & $(1009-1034)$ & \\
\hline \multirow{2}{*}{ ER-beta6 } & ${ }^{*} \mathrm{~F} \llbracket 6$ & $5^{\prime}$ tcttgttctggacaggtatgtaccct $3^{\prime}$ & $(204-229)$ & \multirow{2}{*}{$103 \mathrm{pz}$} \\
\hline & $\mathrm{F} \llbracket 1$ & $5^{\prime}$ atgtaccctctggtcacagcgacc $3^{\prime}$ & $(1646-1669)$ & \\
\hline
\end{tabular}

* oligonucleotide including alternative exon splicing site is indicated/zaznaczono oligonukleotyd obejmujący miejsce alternatywnego składania eksonów 
(TaqMan DNA Template Reagents Kit and $\beta$-actin Control Reagent Kit). The obtained results during $\beta$-actin amplification constituted the basis for plotting a standard curve for each analysis, on the basis of which a sequence detector determined the number of cDNA copies of the tested genes.

Statistical analysis was conducted by means of the STATISTICA programme. The normativity of the obtained results was assessed employing the Shapiro-Wilk test. Due to the fact that some parameters did not have normal distributions, non-parametric Kruskal-Wallis tests were used to assess the differences between the groups. The concentration of each ER-alpha or ER-beta mRNA variant was determined by the number of mRNA variant copies per $1 \mu \mathrm{g}$ of the total RNA. The measure of the transcriptional activity of the ER-alpha and ER-beta genes was the sum of concentrations of all the ER-alpha or ER-beta mRNA variants resulting from post-transcriptional modifications in the studied groups.

The transcriptional activity ratio of the ER-alpha and ER-beta genes is the quotient of the ER-alpha and ER-beta transcriptional activity values determined according to the following formula:

$$
\text { transcriptional activity ratio }=\frac{\sum \text { ER-alfa }}{\sum \text { ER-beta }}
$$

The value of the proportion ratio of a given post-transcriptional ER-alpha or ER-beta modification variant in the total mRNA pool was equal to the quotient of the number of mRNA copies of the variant to the sum of the number of mRNA copies of all the ER-alpha or beta variants:

$$
\begin{gathered}
\text { proportion ratio of ER-alfa mRNA variant }=\frac{\text { ER-alfa } \mathrm{x}}{\Sigma \text { ER-alfa }} \\
\text { proportion ratio of ER-beta mRNA variant }=\frac{\text { ER-beta } \mathrm{x}}{\Sigma \text { ER-beta }}
\end{gathered}
$$

\section{RESULTS}

Based on the NetAffix TM database by Affymetrix and the literature data, 91 mRNA IDs of cytochrome P450 genes were sought, whose transcriptional activity can be analyzed with HG-U133A oligonucleotide microarrays. The one-way ANOVA (one-way analysis of variance) test assessed the statistical significance of the observed differences between the mRNA concentration profiles of cytochrome P450 genes for the control groups and endometrial adenocarcinoma at histological maturity grades G1-G3. It was found that between the transcriptome groups for 91 mRNA IDs, there are statistically significant differences in the intensity of fluorescence signals for 22 mRNA IDs of the cytochrome 450 genes, assuming that $\mathrm{p}<0.05$ (Tab. II). By increasing the criterion of strength of differentiation from $\mathrm{p}<0.02$ to $p<0.001$, a gradual decrease in the number of mRNAs differentiating the transcriptome groups was observed. At a further stage of the analysis, a comparison of endometrial adenocarcinoma transcripts with the control group was conducted with the non-parametric Mann- kinetyki reakcji QRT-PCR z zastosowaniem detektora sekwencji ABI PRISM ${ }^{\mathrm{TM}} 7700$ (TaqMan). Sekwencje oligonukleotydowych starterów do detekcji mRNA ER-alfa i ER-beta zaprojektowano, wykorzystując program komputerowy Primer Express ${ }^{\mathrm{TM}}$ Version 1.0 na podstawie sekwencji badanych genów pochodzących z bazy danych GenBank (http://ncbi.nlm.nih.gov) (tab. I). Równocześnie przeprowadzono amplifikację komercyjnie dostępnego fragmentu genu $\beta$-aktyny $\mathrm{w}$ pięciu różnych stężeniach (od $1 \times 10^{3}$ do $\left.2 \times 10^{4}\right)$ i w trzech powtórzeniach (TaqMan DNA Template Reagents Kit oraz $\beta$-actin Control Reagent Kit). Uzyskane wyniki otrzymane podczas amplifikacji $\beta$-aktyny stanowiły podstawę do wykreślenia dla każdej analizy krzywej standardowej, na podstawie której detektor sekwencji wyznaczył liczbę kopii cDNA badanych genów.

Analizę statystyczną przeprowadzono za pomocą programu STATISTICA. Oceniono normatywność uzyskanych wyników, stosując test Shapiro-Wilka. Z uwagi na to, że niektóre parametry nie miały rozkładów normalnych, dla oceny różnic pomiędzy grupami zastosowano testy nieparametryczne Kruskala-Wallisa.

Stężenie każdego z wariantów mRNA ER-alfa lub ER-beta określała liczba kopii wariantu mRNA w przeliczeniu na $1 \mu \mathrm{g}$ całkowitego RNA. Miarą aktywności transkrypcyjnej genów ER-alfa lub ER-beta była suma stężeń wszystkich wariantów mRNA ER-alfa lub ER-beta powstałych w wyniku potranskrypcyjnych modyfikacji w badanych grupach.

Wskaźnik aktywności transkrypcyjnej genów ER-alfa i ER-beta jest ilorazem wartości aktywności transkrypcyjnej ER-alfa i ER-beta wyznaczonym według następującego wzoru:

$$
\text { wskaźnik aktywności transkrypcyjnej }=\frac{\sum \text { ER-alfa }}{\sum \text { ER-beta }}
$$

Wartość wskaźnika udziału danego wariantu modyfikacji potranskrypcyjnej ER-alfa lub ER-beta w ogólnej puli mRNA była równa ilorazowi liczby kopii mRNA wariantu do sumy liczby kopii mRNA wszystkich wariantów ER-alfa lub beta:

$$
\begin{aligned}
& \text { wskaźnik udziału wariantu mRNA ER-alfa }=\frac{\text { ER-alfa x }}{\Sigma \text { ER-alfa }} \\
& \text { wskaźnik udziału wariantu mRNA ER-beta }=\frac{\text { ER-beta x }}{\Sigma \text { ER-beta }}
\end{aligned}
$$

\section{WYNIKI}

Na podstawie bazy danych NetAffix ${ }^{\mathrm{TM}}$ firmy Affymetrix i danych literaturowych wyszukano 91 ID mRNA genów cytochromu P450, których aktywność transkrypcyjną można analizować z zastosowaniem mikromacierzy oligonukleotydowych HG-U133A. Jednoczynnikowym testem ANOVA (one-way analysis of variance) oceniono znamienność statystyczną obserwowanych różnic pomiędzy profilami stężeń mRNA genów cytochromu P450 dla grup kontrolnych i gruczolakoraka endometrium stopniu histologicznej dojrzałości 
Table II. Number of mRNA IDs of cytochrome P450 mRNA differentiating endometrial adenocarcinoma transcriptomes determined by one-way ANOVA test Tabela II. Liczba ID mRNA cytochromu P450 różnicujacych transkryptomy gruczolakoraka endometrium wyznaczona jednoczynnikowym testem ANOVA

\begin{tabular}{ccccccc}
\hline \multicolumn{6}{c}{ Number mRNAs differentiating K vs G1 vs G2 vs G3/Liczba mRNA różnicujących K vs G1 vs G2 vs G3 } \\
\hline P value/Wartość $p$ & & $p<0,05$ & $p<0,02$ & $p<0,01$ & $p<0,005$ & $p<0,001$ \\
\hline Differentiating/Różnicujace & 91 & 22 & 6 & 4 & 1 & 0 \\
\hline
\end{tabular}

-Whitney U test. Statistically significant results were obtained for 15.4 and 3 mRNAs differentiating G1 vs $\mathrm{K}, \mathrm{G} 2$ vs $\mathrm{K}$ and G3 vs $\mathrm{K}$ respectively. Table III presents by means of heatmaps the visualization of changes in the activity of differential transcriptomes and the multiple fluorescence signal difference, as well as the p-value depending on the degree of histopathological differentiation of adenocarcinoma in relation to the control group.

Using statistical restrictions, 5 specific mRNA IDs of cytochrome P450 genes differentiating endometrial adenocarcinoma of grades G1, G2, G3 from control, $\mathrm{K}$, were identified by the one-way ANOVA test with Benjamini-Hochberg correction (Tab. IV).

Using the Venn diagram the specificity of $5 \mathrm{mRNA}$ IDs of estrogen-dependent genes in the differentiation of adenocarcinoma transcriptomes in relation to the control was assessed (Fig. 1). Gene CYP46A1 with probe number 220331 at differentiates endometrial adenocarcinoma from the control regardless of the grade of histological maturity.

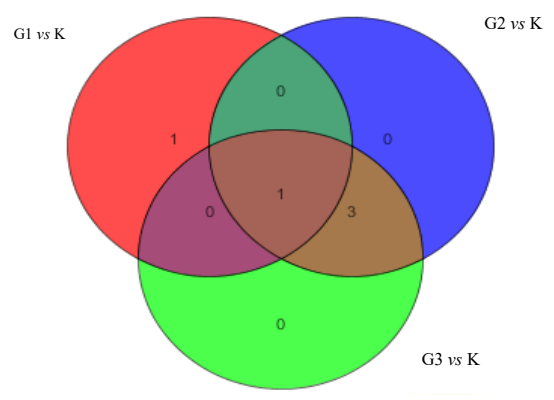

Fig. 1. Venn diagram.

Ryc. 1. Diagram Venna.

The measure of transcriptional activity of the ER-alpha and ER-beta genes was the sum of the concentrations of all the ER-alpha or ER-beta mRNA variants resulting from post-transcriptional modifications in the studied groups, expressed as the number of mRNA copies per $1 \mu \mathrm{g}$ of the total RNA.

In proliferative endometrium, the mean transcriptional activity of the ER-alpha gene was $60.764 \pm 6.332$ mRNA copies. In endometrial adenocarcinoma, the transcriptional activity was $29.996 \pm 3.735$ mRNA copies per $1 \mu \mathrm{g}$ of the total RNA (Table V). A statistically significant difference between the studied groups in the range of the assessed values $(\mathrm{p}<0.01$ Kruskal-Wallis test) was found. A statistically significant decrease was noted in the number of ER-alpha mRNA copies per $1 \mu \mathrm{g}$
G1-G3. Stwierdzono, że między grupami transkryptomów dla 91 ID mRNA występują istotne statystycznie różnice intensywności sygnałów fluorescencji dla 22 ID mRNA genów cytochromu P450, przy założeniu, że wartość $\mathrm{p}<0,05$ (tab. II). Zwiększając kryterium siły różnicowania od wartości $\mathrm{p}<0,02$ do $\mathrm{p}<0,001$, obserwowano stopniowe zmniejszenie liczby mRNA różnicujących grupy transkryptomów.

$\mathrm{Na}$ dalszym etapie analizy przeprowadzono porównanie transkryptów gruczolakoraka endometrium z kontrolą testem nieparametrycznym Manna-Whitneya. Otrzymano istotne statystycznie wyniki dla 15, 4 i 3 mRNA różnicujących odpowiednio $\mathrm{G} 1$ vs $\mathrm{K}, \mathrm{G} 2$ vs $\mathrm{K}$ i G3 vs K. W tabeli III przedstawiono za pomocą map „ciepła” (heatmap) wizualizację zmian aktywności transkryptomów różnicujących oraz wielokrotność różnicy sygnałów fluorescencji i wartość p w zależności od stopnia zróżnicowania histopatologicznego gruczolakoraka w odniesieniu do kontroli.

Stosując restrykcje statystyczne testem jednoczynnikowym ANOVA z poprawką Benjamini-Hochberg, wytypowano 5 specyficznych ID mRNA genów cytochromu P450 różnicujących gruczolakoraka endometrium w stopniach G1,G2 i G3 od kontroli K (tab. IV).

Wykorzystując diagram Venna, oceniono specyficzność 5 ID mRNA estrogenozależnych genów w różnicowaniu transkryptomów gruczolakoraka w odniesieniu do kontroli (ryc. 1). Gen CYP46A1 o numerze sondy 220331 at różnicuje gruczolakoraka endometrium od kontroli niezależnie od stopnia histologicznej dojrzałości.

Miarą aktywności transkrypcyjnej genów ER-alfa i ER-beta była suma stężeń wszystkich wariantów mRNA ER-alfa lub ER-beta, powstałych w wyniku potranskrypcyjnych modyfikacji w badanych grupach, wyrażona liczbą kopii mRNA w przeliczeniu na $1 \mu \mathrm{g}$ całkowitego RNA.

W endometrium proliferacyjnym średnia aktywność transkrypcyjna genu ER-alfa wynosiła $60764 \pm 6332$ kopii mRNA, w gruczolakoraku endometrium - 29996 \pm 3735 kopii mRNA w przeliczeniu na $1 \mu \mathrm{g}$ całkowitego RNA (tab. V). Stwierdzono różnicę istotną statystycznie pomiędzy badanymi grupami w zakresie ocenianych wartości ( $\mathrm{p}<0,01$ test Kruskala-Wallisa). Odnotowano statystycznie istotny spadek liczby kopii mRNA ER-alfa $\mathrm{w}$ przeliczeniu na $1 \mu \mathrm{g}$ całkowitego RNA w zależności od stopnia zaawansowania potencjału transformacji nowotworowej.

W endometrium proliferacyjnym średnia aktywność transkrypcyjna genu ER-beta wynosiła $38874 \pm 3870$ kopii mRNA, w gruczolakoraku endometrium - 13920 
Table III. Multiple fluorescence signal difference for mRNA ID CYPs ( $F C-\log _{2}$ parameter) and their differential strength ( $p$-value) of endometrial biopsy specimens depending on grade of histopathological differentiation of adenocarcinoma in relation to control $K$ group and heatmap A) $G 1$ vs $K, B) G 2$ vs $K, C) G 3$ vs $K$ Tabela III. Wielokrotność różnicy sygnałów fluorescencji ID mRNA CYPs (parametr FC- $\log _{2}$ ) oraz ich siła różnicowania (wartość p) wycinków endometrium zależności od stopnia zróżnicowania histopatologicznego gruczolakoraka w odniesieniu do kontroli K oraz „mapy goraca” A) G1 vs K, B) G2 vs K, C) G3 vs K

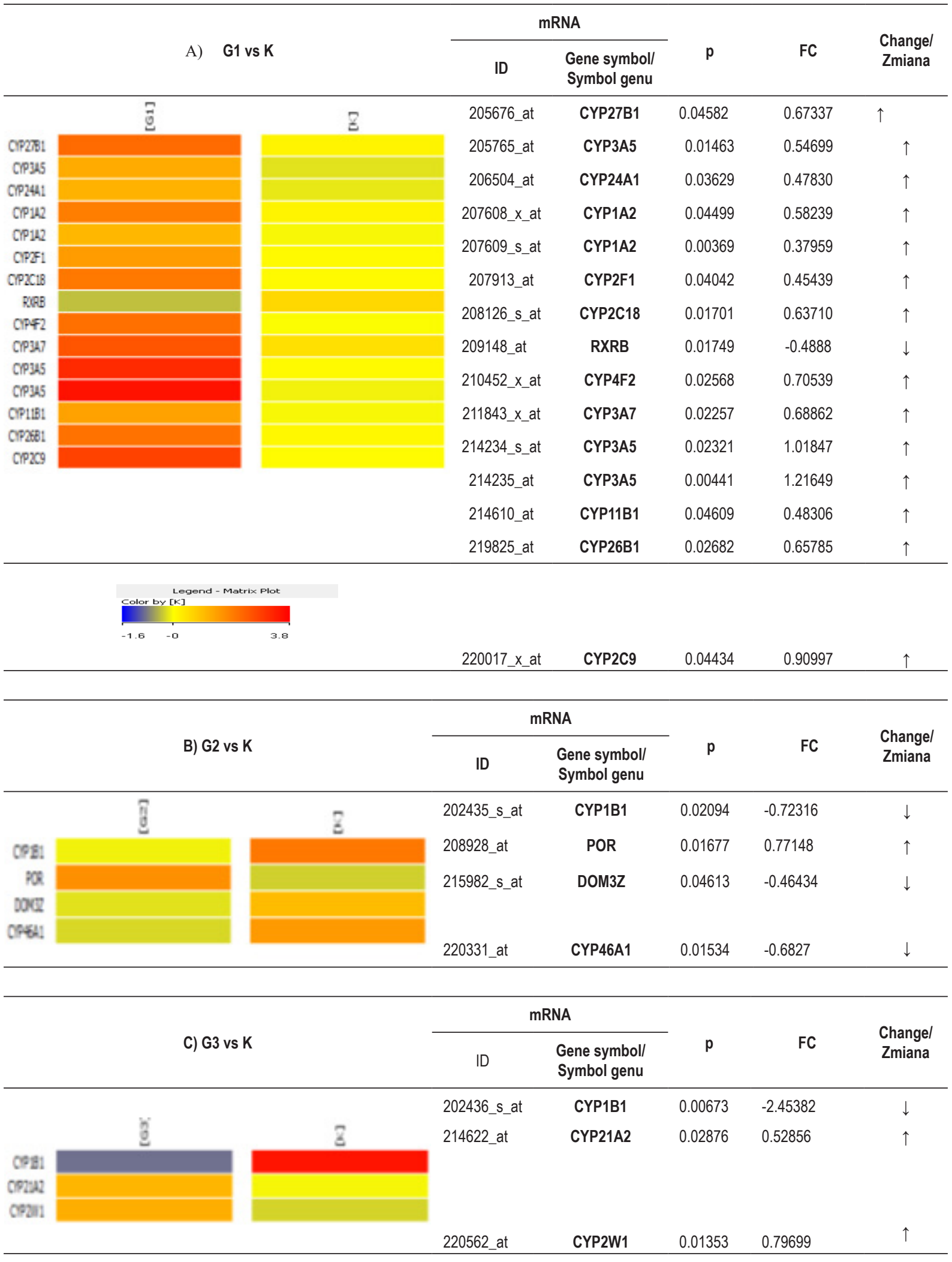


Table IV. Cytochrome P450 genes differentiating cancer from normal endometrium and direction of changes in expression Tabela IV. Geny cytochromu P450 różnicujące raka od prawidłowego endometrium oraz kierunek zmian ekspresji

\begin{tabular}{|c|c|c|c|c|c|c|c|c|}
\hline \multicolumn{2}{|c|}{ mRNA } & \multirow{2}{*}{ Wartość $p<0,05$} & \multicolumn{6}{|c|}{ FC (Fold change) $\log _{2}$} \\
\hline ID & Symbol & & \multicolumn{2}{|c|}{ G1 vs $K$} & \multicolumn{2}{|c|}{ G2 vs $\mathrm{K}$} & \multicolumn{2}{|c|}{ G3 vs $\mathrm{K}$} \\
\hline 202434_s_at & CYP1B1 & $2.847 \cdot 10^{-4}$ & 1.6845 & $\uparrow$ & 1.2477 & $\uparrow$ & 1.1693 & $\uparrow$ \\
\hline 202435_s_at & CYP1B1 & $3.837 \cdot 10^{-12}$ & 1.2348 & $\uparrow$ & -2.3347 & $\downarrow$ & -2.3499 & $\downarrow$ \\
\hline 202436_s_at & CYP1B1 & $6.512 \cdot 10^{-7}$ & 1.6106 & $\uparrow$ & -3.8198 & $\downarrow$ & -2.7310 & $\downarrow$ \\
\hline 202437_s_at & CYP1B1 & $9.213 \cdot 10^{-6}$ & 1.0703 & $\uparrow$ & -4.3701 & $\downarrow$ & -3.5993 & $\downarrow$ \\
\hline 220331_at & CYP46A1 & $5.096 \cdot 10^{-4}$ & -1.6267 & $\downarrow$ & -2.0617 & $\downarrow$ & -1.6712 & $\downarrow$ \\
\hline
\end{tabular}

Table V. Transcriptional activity of ER-alpha and ER-beta genes and ER-alpha/ER-beta ratio in proliferative endometrium and endometrial adenocarcinoma Tabela V. Aktywność transkrypcyjna genów ER-alfa i ER-beta oraz wskaźnik ER-alfa/ER-beta w endometrium proliferacyjnym i gruczolakoraku endometrium

\begin{tabular}{lccc}
\hline \multicolumn{1}{c}{ Grup/Grupa } & $\begin{array}{c}\text { ER-alpha sum (mean } \pm \text { SEM)/ } \\
\text { Suma ER-alfa (średnia } \pm \text { SEM) }\end{array}$ & $\begin{array}{c}\text { ER-beta sum (mean } \pm \text { SEM)/ } \\
\text { Suma ER-beta (średnia } \pm \text { SEM) }\end{array}$ & $\begin{array}{c}\text { ER-alpha/ER-beta (mean } \pm \text { SEM)/ } \\
\text { ER-alfa/ER-beta (średnia } \pm \text { SEM) }\end{array}$ \\
\hline $\begin{array}{l}\text { Normal endometrium/ } \\
\begin{array}{l}\text { Endometrium prawidłowe } \\
\text { Endometrial adenocarcinoma/ }\end{array}\end{array}$ & $60764 \pm 6332$ & $38874 \pm 3870$ & $1.645 \pm 0.128$ \\
\hline
\end{tabular}

of the total RNA depending on the stage of neoplastic transformation potential.

The mean transcriptional activity of the ER-beta gene in proliferative endometrium was $38.874 \pm 3.870 \mathrm{mRNA}$ copies. In endometrial adenocarcinoma the value was equal to $13.920 \pm 2.115 \mathrm{mRNA}$ copies per $1 \mu \mathrm{g}$ of the total RNA.

By analyzing the expression of ER-alpha and ER-beta genes, an assessment of the ratio of transcriptional activity equal to the quotient of transcriptional activity of the studied genes was carried out, assuming that the transcriptional activity of the gene was the sum of the mean concentrations of all the ER-alpha or ER-beta mRNA variants in the studied groups. In the case of proliferative endometrium, it was found that the ratio was equal to $1.645 \pm 0.128$, while in endometrium adenocarcinoma the value was $2.445 \pm 0.172$.

Eight pairs of starter sets and hybridization probes were designed for the detection and quantitative assessment of the ER-alpha mRNA alternative splicing products based on the literature data presented by Green et al. Nucleotide sequences characteristic of only one ER-alpha isoform were identified, confirming the specificity in the BLAST program. In order to detect the isoforms, one of the starters was designed in such way that it would hybridize an area encompassing the boundaries of exons joined as result of alternative splicing.

The most commonly found isoform in proliferative endometrium was ER-alpha/delta7 (87.5\%), and the ER-alpha/delta5 isoform was not found in any of the studied samples. ER-alpha/delta2 and ER-alpha/delta3 were present in 58.3 and $62.5 \%$ of the assessed samples. ER-alpha/delta5 was found in all the examined fragments of adenocarcinoma (100\%). ER-alpha/delta7 and ER-alpha/delta2 were slightly less common; respectively in $78.9 \%$ and $63.2 \%$ of cases.

Seven pairs of starters and hybridization probes were designed for the detection and quantitative assessment of the ER-beta mRNA alternative splicing products in \pm 2115 kopii mRNA w przeliczeniu na $1 \mu \mathrm{g}$ całkowitego RNA.

Analizując ekspresję genów ER-alfa i ER-beta, przeprowadzono ocenę wskaźnika aktywności transkrypcyjnej równej ilorazowi aktywności transkrypcyjnej badanych genów, przyjmując za aktywność transkrypcyjną genu sumę średnich stężeń wszystkich wariantów mRNA ER-alfa lub ER-beta w badanych grupach. W endometrium proliferacyjnym stwierdzono, że wskaźnik ten był równy $1,645 \pm 0,128$, natomiast gruczolakoraku endometrium $-2,445 \pm 0,172$.

Zaprojektowano osiem par zestawów starterów i sond hybrydyzacyjnych do detekcji i oceny ilościowej produktów alternatywnego składania mRNA ER-alfa na podstawie danych literaturowych przedstawionych przez Greena i wsp. Wyznaczono sekwencje nukleotydowe charakterystyczne tylko dla jednej izoformy ER-alfa, potwierdzając specyficzność w programie BLAST. W celu detekcji izoform jeden ze starterów został zaprojektowany w ten sposób, aby hybrydyzował z obszarem obejmującym granice eksonów połączonych w wyniku alternatywnego składania.

$\mathrm{W}$ endometrium proliferacyjnym najczęściej stwierdzaną izoformą był ER-alfa/delta7 $(87,5 \%)$, natomiast izoforma ER-alfa/delta5 nie wystapiła w żadnej badanej próbce. ER-alfa/delta2 i ER-alfa/delta3 obecne były u $58,3 \%$ i $62,5 \%$ ocenianych. We wszystkich badanych fragmentach gruczolakoraka wykazano ER-alfa/delta5 (100\%). Nieco rzadziej występowała ER-alfa/delta7 $(78,9 \%)$ i ER-alfa/delta2 $(63,2 \%)$.

Do detekcji i oceny ilościowej produktów alternatywnego składania mRNA ER-beta zaprojektowano siedem par zestawów starterów i sond hybrydyzacyjnych w ten sposób, by hybrydyzowały z obszarem obejmującym sekwencje graniczne macierzystego i obcego fragmentu nukleotydowego, należącego do eksonu ósmego. Izoformę ER-beta5 odnotowano u każdej badanej, podobnie jak formę dziką ER-beta. W endometrium proliferacyjnym izoforma ER-beta2 występowała w każdej 
such way that they would hybridize an area encompassing the borderline sequences of the original and foreign nucleotide fragment, belonging to the eighth exon. The ER-beta5 isoform was observed in each patient, as was the wild form of ER-beta. The ER-beta2 isoform was present in each sample of proliferative endometrium. The ER-beta3 and ER-beta4 variants were present in 16.7 and $45.9 \%$. ER-beta5 was also found to be present in all the examined adenocarcinoma samples. $31.6 \%$ of positive results characterized the ER-beta 3 and ER-beta4 isoforms, and ER-beta 2 was present in $84.2 \%$ cases of endometrial cancer.

\section{DISCUSSION}

The development of modern methods of molecular biology, especially introduction of the oligonucleotide microarray technique, provides chance to classify cancer on the basis of its molecular profile. Compared to qualitative analysis, the quantitative analysis of mRNA undoubtedly enables more accurate knowledge to be gained regarding the changes occurring in subsequent stages of carcinogenesis. Currently, the diagnosis of endometrial pathology is based on pathomorphological assessment; however, not all cases of endometrial cancer are diagnostically simple. Great hopes are associated with the development of molecular diagnostic methods, the application of which will enable pathologies to be diagnosed before the occurrence of pathomorphological changes. Hence the search for molecular markers of neoplastic transformation.

In the case of endometrial cancer, no screening tests are available, and the symptoms of the disease are not very specific and occur relatively late. The correlation between the occurrence of this cancer and estrogens is commonly known. Due to their mitogenic activity, estrogens play a significant role in the development of all ER-positive cancers [13]. These hormones may not only promote the development of cancers by stimulating proliferation, changes in gene differentiation and expression, but also initiate the process of carcinogenesis through reactive metabolites created with the involvement of the enzymes of the cytochrome P450 complex [14]. The main estrogen in women, i.e. $17 \beta$-estradiol $\left(\mathrm{E}_{2}\right)$, on the one hand is substrate for the enzymes of the 1st phase of metabolism (CYP1A1, CYP1A2, CYP1B1), which in turn leads to the production of active 2- and 4-hydroxycathechols, and on the other $\mathrm{E}_{2}$ is a ligand for the estrogen receptor considered to be a transcription factor. Initiation of the endogenous carcinogenesis process in the endometrium by reactive estrogen metabolites is associated with damage to the DNA caused by adduct formation. The mechanism of their formation is primarily studied in the case of mammary gland cancers, for which estrogens are also considered to be the main risk factor in the etiopathogenesis [16].

As transcription factors, estrogen receptors directly or indirectly influence the expression of a number of ge- próbce. Warianty ER-beta3 i ER-beta4 obecne były u 16,7\% i 45,9\%. Również we wszystkich badanych próbkach gruczolakoraka ujawniono ER-beta5. 31,6\% wyników pozytywnych charakteryzowało izoformy ER-beta3 i ER-beta4, a ER-beta2 obecna była w 84,2\% przypadków raka endometrium.

\section{DYSKUSJA}

Rozwój nowoczesnych metod biologii molekularnej, a zwłaszcza wprowadzenie techniki mikromacierzy oligonukleotydowych, stwarza szanse na klasyfikację nowotworu na podstawie jego profilu molekularnego. Analiza ilościowa mRNA, w porównaniu $\mathrm{z}$ analizą jakościową, pozwala niewątpliwie na dokładniejsze poznanie zmian zachodzących na kolejnych etapach kancerogenezy. Obecnie rozpoznanie patologii endometrium opiera się na ocenie patomorfologicznej, ale nie wszystkie przypadki raka endometrium są diagnostycznie proste. Duże nadzieje wiąże się z opracowaniem molekularnych metod rozpoznawczych, których zastosowanie umożliwi zdiagnozowanie patologii przed zmianami patomorfologicznymi. Stąd też poszukuje się molekularnych markerów transformacji nowotworowej.

W raku endometrium nie dysponujemy badaniem skriningowym, a jego objawy są mało charakterystyczne i pojawiają się stosunkowo późno. Powszechnie znany jest związek występowania tego nowotworu $\mathrm{z}$ estrogenami. Hormony te, ze względu na swoją mitogenną aktywność, odgrywają znaczącą rolę we wzroście wszystkich ER-pozytywnych raków [13]. Mogą nie tylko promować rozwój nowotworów poprzez stymulację proliferacji, zmiany różnicowania i ekspresji genów, ale także inicjować proces kancerogenezy za pośrednictwem reaktywnych metabolitów powstałych przy udziale enzymów kompleksu cytochromu P450 [14]. Główny estrogen kobiet, tj. 17 $\beta$-estradiol $\left(E_{2}\right)$, z jednej strony jest substratem dla enzymów I fazy metabolizmu (CYP1A1, CYP1A2, CYP1B1), co w efekcie prowadzi do produkcji aktywnych 2- i 4-hydroksykatecholi, a $z$ drugiej $E_{2}$ jest ligandem dla receptora estrogenowego uważanego za czynnik transkrypcyjny [15]. Inicjalizacja procesu kancerogenezy endometrium przez reaktywne metabolity estrogenów wiąże się uszkodzeniem DNA wywołanym tworzeniem adduktów. Mechanizm ich tworzenia bada się przede wszystkim w przypadku nowotworów gruczołu piersiowego, dla których również estrogeny są postrzegane jako główny czynnik ryzyka w etiopatogenezie [16].

Receptory estrogenowe jako czynniki transkrypcyjne wpływają bezpośrednio lub pośrednio na ekspresje szeregu genów, hamując lub nasilając ją, a więc tym samym stanowia istotne ogniwo łańcucha przemian dokonujących się zarówno w prawidłowej, jak i nowotworowej tkance. Jest wysoce prawdopodobne, że tkanki nowotworowe zmieniają sygnalizację zależną od receptorów estrogenowych. Według Hirata i wsp. znaczącą rolę w onkogenezie estrogenozależnych tkanek 
nes, either inhibiting or intensifying it; they, therefore constitute significant element of the chain of transformations occurring in both healthy and neoplastic tissue. It is highly likely that neoplastic tissues change signaling dependent on estrogen receptors. According to Hirat et al., the variants of ER mRNA alternative splicing play a significant role in the oncogenesis of estrogen-dependent tissues [17].

The paper presents the assessment of the ER-alpha and ER-beta gene expressions in the case of endometrial adenocarcinoma as well endometrium without neoplastic changes. The types of ER mRNA alternative splicing in post-transcriptional modifications and their expressions were determined. The presented results document the presence of ER-alpha and ER-beta mRNA in proliferative endometrium and adenocarcinoma; the expression of the ER-alpha gene was significantly higher compared to ER-beta. In cancer tissues, the transcriptional activity of the ER-alpha and ER-beta genes decreases, and the transcriptional activity ratio expressed by the quotient of transcriptional activity of the ER-alpha and ER-beta genes, increases. These data confirm the dominating significance of ER-alpha in the endometrium. Even though the level of ER-beta expression was significantly lower than ER-alpha, it is this receptor that may affect the biology of the carcinogenesis. The decrease in ER-beta mRNA expression during carcinogenesis in estrogen-dependent cancers, which many authors describe, suggests that this receptor may not act only as a physiological inhibitor of growth processes, but also a suppressor of carcinogenesis [18]. Gustafsson proposed a hypothesis on the protective role of ER-beta in the processes of carcinogenesis [19]. This hypothesis is confirmed by the decrease in the transcriptional activity of the ER-beta gene noted in this study. Kato et al. demonstrated correlation between the increase in ER-alpha mRNA expression with endometrium hyperplasia conversion into G1 adenocarcinoma [20].

The significance of ER-alpha and ER-beta in the studied material was also determined on the basis of the change in the transcriptional activity ratio, determined by the quotient of the transcriptional value of the ER-alpha and ER-beta gene. The transcriptional activity ratio of the ER-alpha and ER-beta gene in proliferative endometrium was $1.645 \pm 0.128$, whereas in adenocarcinoma it was $2.445 \pm 0.172$, which testifies to the decreasing role of ER-alpha in intracellular estrogen signaling over the course of pathology development.

Analyzing the proportion ratio of the assessed variants of ER-alpha gene alternative splicing, it was found that ER-alpha/delta5 isoform expression was not found in any of the studied cases of proliferative endometrium, while the ratio grew significantly in endometrial adenocarcinoma. Higher values of the expression of the ER-alpha/delta2, ER-alpha/delta3 and ER/delta6 isoforms were also observed in cancer tissue, compared to endometrium without neoplastic changes.

The ER-alpha/delta5 and ER-alpha/delta6 isoforms, lacking exons coding the LBD fragment, determine the hormone-dependent AF2 transactivation and li- odgrywają warianty alternatywnego składania mRNA ERs [17].

W niniejszej pracy przedstawiono ocenę ekspresji genów ER-alfa i ER-beta w gruczolakoraku endometrium oraz endometrium niezmienionym nowotworowo. Wyznaczone zostały typy alternatywnego składania mRNA receptorów estrogenowych w modyfikacjach potranskrypcyjnych i ich ekspresje. Przedstawione wyniki dokumentują obecność mRNA i ER-alfa ER-beta w endometrium proliferacyjnym i gruczolakoraku, przy czym ekspresja genu ER-alfa była znamiennie wyższa w porównaniu $\mathrm{z}$ ER-beta. W tkankach nowotworowych aktywność transkrypcyjna genów ER-alfa i ER-beta zmniejsza się, a wskaźnik aktywności transkrypcyjnej, wyrażony ilorazem aktywności transkrypcyjnej genów ER-alfa i ER-beta, wzrasta. Dane te potwierdzają dominujące znaczenie ER-alfa w endometrium. Mimo że poziom ekspresji ER-beta był znacznie niższy niż ER-alfa, to właśnie ten receptor może mieć wpływ na biologię nowowtworzenia.

Opisywany przez wielu autorów spadek ekspresji mRNA ER-beta podczas karcinogenezy w estrogenozależnych nowotworach sugeruje, że receptor ten może pełnić rolę nie tylko fizjologicznego inhibitora procesów wzrostowych, ale także supresora karcinogenezy [18]. Gustafsson wysunął hipotezę o protekcyjnej roli ER-beta w procesach nowotworzenia [19]. Odnotowany w niniejszej pracy spadek aktywności transkrypcyjnej genu ER-beta potwierdza tę hipotezę. Kato i wsp. [20] wykazali zależność między wzrostem ekspresji mRNA ER-alfa $z$ konwersją rozrostu endometrium do wysoko zróżnicowanego gruczolakoraka.

Znaczenie ER-alfa i ER-beta w badanym materiale wyznaczono także na podstawie zmiany wskaźnika aktywności transkrypcyjnej, określonego ilorazem wartości transkrypcyjnej genów ER-alfa i ER-beta. Wskaźnik aktywności transkrypcyjnej genów ER-alfa i ER-beta $\mathrm{W}$ endometrium proliferacyjnym wynosił $1,645 \pm$ 0,128 , natomiast $\mathrm{w}$ gruczolakoraku $2,445 \pm 0,172$, co świadczy o zmniejszaniu się roli ER-alfa w wewnątrzkomórkowej sygnalizacji estrogenowej w miarę narastania patologii.

Analizując wskaźnik udziału ocenianych wariantów alternatywnego składania genu ER-alfa stwierdzono, że w żadnym $\mathrm{z}$ badanych przypadków endometrium proliferacyjnego nie ujawniono ekspresji izoformy ER-alfa/ delta5, natomiast stwierdzono znamienny wzrost tego wskaźnika w gruczolakoraku endometrium. W tkance nowotworowej także obserwowano wyższe wartości ekspresji izoformy ER-alfa/dela2, ER-alfa/delta3 i ER/ delta6 $\mathrm{W}$ porównaniu $\mathrm{z}$ endometrium niezmienionym nowotworowo.

Izoformy ER-alfa/delta5 i ER-alfa/delta6, z brakiem eksonów kodujących fragment LBD, decydują o hormonozależnej transaktywacji AF2 i wiązaniu ligandu. Ekspresję ER-alfa/delta5 wykazano w raku endometrium i raku szyjki macicy, a zaobserwowany w tych przypadkach wzrost ekspresji tej izoformy wiązał się z klinicznymi cechami wzrostu agresywności nowotworu [21]. Także w innym nowotworze estrogenoza- 
gand binding. The expression of ER-alpha/delta5 was demonstrated in endometrial and cervical cancer, and the increase in the expression of the isoform observed in these cases was associated with clinical features of increased aggressiveness of the cancer [21]. Also, in another estrogen-dependent cancer, breast cancer, an increase in the expression of ER-alpha/delta5 compared to healthy tissue was described [22]. Fujimoto et al. defined the ER/delta5 isoform as a factor with high transcriptional activity potential [23].

As a result of the conducted studies, it was found that in as many as $87.5 \%$ of cases of endometrium without neoplastic changes, positive results of ER-alpha/delta7 mRNA were obtained. On the other hand, a higher percentage of negative results was observed in endometrial adenocarcinoma. The decrease in ER-alpha/delta7 expression in this cancer may prove the protective role of the isoform in the process of carcinogenesis.

The ER-beta5 isoform was found in all the studied samples, both proliferative endometrium and adenocarcinoma. Unlike ER-alpha/delta5, the isoform does not act as a positively dominating receptor and does not activate gene transcription in the absence of ligand. The dimerization of ER-beta5 with ER-alpha or ER-beta inhibits both transactivation processes. As consequence, this isoform is a physiological inhibitor of transcription processes and belongs to negatively dominating receptors [24]. According to Chi et al., ER-beta5 expression is associated with larger size of tumor and higher proliferative activity in the case of breast cancer [25]. The presence of such a profile of alternative splicing variants in endometrial adenocarcinoma, different than endometrium without neoplastic changes, may indicate that the number of transcription errors is associated with genetic changes increasing the risk of carcinogenesis.

Analysis of the results obtained in the array experiment confirmed the increase in the CYP1B1 transcriptional activity in G1 endometrial adenocarcinoma with regard to normal endometrium. This increase in gene expression is observed only in G1 endometrial adenocarcinoma. In subsequent grades, a strong decrease in CYP1B1 expression is observed. Due to the fact that the level of CYP1B1 202434_s_at mRNA was significantly higher in cancer cells in the $\mathrm{G} 1$ phase compared to the others studied in the function of cytochrome P450, it can be defined as a molecular signature of the neoplastic transformation process in the endometrium. The increased level of CYP1B1 mRNA may promote the formation of reactive estrogen metabolites, which can initiate the neoplastic process; on the other hand, the activity of CYP1B1 may decrease the level of estrogens in the endometrial tissue.

The specificity of 5 mRNA IDs of estrogen-dependent genes in the differentiation of adenocarcinoma transcriptomes with respect to the control was assessed using the Venna diagram. From the group of 2 mRNA IDs selected as differentiating G1 endometrial adenocarcinoma from control K, 1 mRNA ID specific for the G1 grade, corresponding to the CYP1B1 gene with probe number 202434_s_at on the HG-U133A microarray leżnym, jakim jest rak sutka, został opisany wzrost ekspresji ER-alfa/delta5 w porównaniu ze zdrową tkanką [22]. Fujimoto i wsp. określili izoformę ER/delta5 jako czynnik o wysokim potencjale aktywności transkrypcyjnej [23].

W wyniku przeprowadzonych badań stwierdzono, że aż w 87,5\% przypadków endometrium niezmienionego nowotworowo uzyskano pozytywne wyniki mRNA ER-alfa/delta7. Natomiast większy odsetek wyników negatywnych odnotowano w gruczolakoraku endometrium. Zmniejszenie ekspresji ER-alfa/delta7 w tym nowotworze może świadczyć o protekcyjnej roli omawianej izoformy w procesie karcinogenezy.

We wszystkich badanych próbkach zarówno endometrium proliferacyjnego, jak i gruczolakoraka, stwierdzono izoformę ER-beta5, która w przeciwieństwie do ER-alfa/delta5 nie działa jak dominujący pozytywnie receptor, nie aktywuje transkrypcji genowej przy braku ligandu. Dimeryzacja ER-beta5 z ER-alfa lub ER-beta hamuje oba procesy transaktywacyjne. W konsekwencji izoforma ta jest fizjologicznym inhibitorem procesów transkrypcyjnych i należy do dominujących negatywnie receptorów [24]. Według Chi i wsp. [25] ekspresja ER-beta5 ma związek z większym rozmiarem guza i wyższą aktywnością proliferacyjną w przypadku raka sutka. Obecność w gruczolakoraku endometrium takiej liczby izoform receptorów estrogenowych, powstałych w procesie alternatywnego składania, może wiązać się ze zwiększeniem liczby pomyłek transkrypcyjnych i w konsekwencji prowadzić do nasilenia procesu karcinogenezy.

Analiza wyników uzyskanych w eksperymencie macierzowym potwierdziła wzrost aktywności transkrypcyjnej CYP1B1 w stopniu G1 gruczolakoraka endometrium $\mathrm{W}$ odniesieniu do endometrium prawidłowego. Ten wzrost ekspresji genu jest obserwowany tylko dla stopnia histologicznego zróżnicowania G1 gruczolakoraka endometrium. W kolejnych stopniach obserwowane jest silne zmniejszenie ekspresji CYP1B1. W związku z tym, że poziom mRNA CYP1B1 202434_s_at był zdecydowanie wyższy w stopniu G1 niż w pozostałych badanych komórkach endometrium, można takie zmiany określić jako wczesny sygnator molekularny procesu transformacji nowotworowej gruczolakoraka. Zwiększony poziom mRNA CYP1B1 może z jednej strony sprzyjać tworzeniu reaktywnych metabolitów estrogenów, które mogą inicjować proces nowotworowy, z drugiej zaś strony działanie CYP1B1 może obniżać poziom estrogenów w tkance endometrium.

Wykorzystując diagram Venna, oceniono specyficzność 5 ID mRNA estrogenozależnych genów w różnicowaniu transkryptomów gruczolakoraka w odniesieniu do kontroli. Z grupy 2 ID mRNA wytypowanych jako różnicujące gruczolakoraka endometrium w stopniu histologicznego zróżnicowania G1 od kontroli (K), wyodrębniono 1 ID mRNA specyficzny dla stopnia G1, który odpowiada genowi CYP1B1 o numerze sondy 202434_s_at na mikromacierzy HG-U133A (Affymetrix). Dla stopnii G2 i G3 brak jest specyficznych ID 
(Affymetrix) was distinguished. There are no specific mRNA IDs of estrogen-dependent isoenzymes of cytochrome P450 for grades G2 and G3. 3 mRNA IDs of the CYP1B1 gene with probe numbers 202435_s_at, 202436 s at, 202437 s at were included in the group of IDs differentiating endometrial adenocarcinoma of Grade 2 and 3 in relation to control $\mathrm{K}$. In the group of 4 mRNA IDs differentiating Grade 3 endometrial adenocarcinoma in relation to the control there are 3 mRNA IDs shared with Grade 2 and one ID differentiating the endometrial adenocarcinoma specimens from the control (Fig. 1). The CYP46A1 gene with probe number220331_at differentiates endometrial adenocarcinoma from the control regardless of the level of histological maturity.

Cytochrome 46A1 participates in cholesterol metabolism and occurs mainly in the neurons of the central nervous system [26]. The results of our study indicate the presence of this cytochrome also in estrogen-dependent endometrial tissue. The role of this cytochrome is to oxidize cholesterol to $24 \mathrm{~s}$-hydroxycholesterol (oxysterol), which is more polar than cholesterol. In addition, testosterone and progesterone, binding and oxidizing a number of drugs are also substrates for this enzyme.

Changes in the composition of functionally active ER variants may, therefore, disturb the estrogen signaling system. Changes in the expression of estrogen-dependent genes of cytochrome P450 may affect the biology and characteristics of the neoplasm.

\section{CONCLUSIONS}

The changes in the transcriptional profile of the studied genes in endometrial adenocarcinoma in correlation to proliferative endometrium described in this paper may indicate that the signaling system mediated by estrogens may be associated with changes triggering carcinogenesis. In conclusion:

1. The expression of ER-alpha and ER-beta genes occurs in proliferative endometrium and in endometrial carcinoma, with ER-alpha being dominant in neoplastic tissue.

2. The increased ratio of transcriptional activity of the genes coding estrogen receptors in endometrial adenocarcinoma indicates a decreased proportion of ER-beta in the total pool of ER $\mathrm{mRNa}$ and indicates the involvement of estrogen receptors in carcinogenesis.

3. The high concentrations of ER-alpha/delta5, ER-alpha/deltaE7 and ER-alpha/deltaE2 in endometrial adenocarcinoma indicate the possibility to use these variants of post-transcriptional modifications of ER mRNA as sensitive markers of molecular progressions of cancer.

4. The gene which possibly differentiates endometrial adenocarcinoma transcriptomes from normal endometrium is CYP46A1.
mRNA estrogenozależnych izoenzymów cytochromu P450. Do grupy różnicujących gruczolakoraka endometrium w stopniach G2 i G3 stosunku do kontroli (K) zaliczono 3 ID mRNA genu CYP1B1 o numerach sond: 202435 s at, 202436 s at, 202437 s at. W grupie 4 ID mRNĀ różnicujących stopień G3 $\overline{3}$ gruczolakoraka endometrium w stosunku do kontroli występują 3 ID mRNA wspólne stopniem G2 oraz 1 ID różnicujący wycinki gruczolakoraka endometrium od kontroli (ryc. 1). Gen CYP46A1 o numerze sondy 220331_at różnicuje gruczolakoraka endometrium od kontroli niezależnie od stopnia histologicznej dojrzałości.

Cytochrom 46A1 bierze udział w metabolizmie cholesterolu i występuje głównie w neuronach centralnego systemu nerwowego [26]. Wyniki naszego badania wskazują na obecność tego cytochromu także w estrogenozależnej tkance endometrium. Rola tego cytochromu polega na utlenianiu cholesterolu do 24 s-hydroksycholesterolu (oksysterolu), który jest bardziej polarny niż cholesterol. Poza tym substratami dla tego enzymu, który wiąże utlenia szereg leków, są testosteron i progesteron.

Zmiany składzie aktywnych funkcjonalnie wariantów ERs mogą więc zaburzać estrogenowy system sygnalizacji. Zmiany ekspresji estrogenozależnych genów cytochromu P450 mogą wpływać na biologię i charakterystykę nowotworu.

\section{WNIOSKI}

Opisane w prezentowanej pracy zmiany profilu transkrypcyjnego badanych genów w gruczolakoraku endometrium w korelacji do endometrium proliferacyjnego mogą wskazywać, że mediowany przez estrogeny system sygnalizacji może mieć związek ze zmianami uruchamiającymi karcinogenezę.

Podsumowując:

1. Ekspresja genów ER-alfa i ER-beta występuje w endometrium proliferacyjnym i gruczolakoraku endometrium, przy czym w tkance nowotworowej dominuje ER-alfa.

2. Wzrost wskaźnika aktywności transkrypcyjnej genów kodujących receptory estrogenowe $\mathrm{w}$ gruczolakora$\mathrm{ku}$ endometrium świadczy o zmniejszeniu udziału ER-beta w całkowitej puli mRNA ERs i wskazuje na udział receptorów estrogenowych w kancerogenezie.

3. Wysokie stężenie ER-alfa/delta5 orazER-alfa/deltaE7 i ER-alfa/deltaE2 w gruczolakoraku endometrium świadczy o możliwości wykorzystania tych wariantów modyfikacji potranskrypcyjnych mRNA ERs jako czułych markerów molekularnych progresji nowotworu.

4. Genem kandydującym do miana różnicujących transkryptomy gruczolakoraka endometrium od endometrium prawidłowego jest CYP46A1.

5. Zmiany ekspresji 4 ID mRNA CYP1B1 na mikromacierzy HG-U133A (Affymetrix) mogą stanowić dodatkowy marker w ocenie stopnia histopatologicznego gruczolakoraka endometrium. 
5. Changes in the expression of 4 IDs of CYP1B1 mRNA on the HG-U133A microarray (Affymetrix) may constitute an additional marker in the assessment of the histopathological grade of endometrial adenocarcinoma.

The study was financed from the statutory research funds of the Department of Gynecology and Obstetrics of the Medical University of Silesia in Katowice - agreement no. KNW-1-129/N/4/0.
Praca finansowana ze środków badań statutowych Kliniki Ginekologii i Położnictwa Śląskiego Uniwersytetu Medycznego w Katowicach - umowa nr KNW-1$129 / \mathrm{N} / 4 / 0$.

\author{
Author's contribution \\ Study design - A. Witek, A. Jęda-Golonka \\ Data collection - A. Jęda-Golonka, A. Witek \\ Data interpretation - A. Witek, A. Jęda-Golonka, M. Paul-Samojedny, C. Kruszniewska-Rajs \\ Statistical analysis - A. Jęda-Golonka, A. Witek, M. Paul-Samojedny, C. Kruszniewska-Rajs \\ Manuscript preparation - A. Jęda-Golonka, A. Witek \\ Literature research - A. Jęda-Golonka, A. Witek, M. Paul-Samojedny
}

\section{REFERENCES}

1. Raporty na podstawie danych Centrum Onkologii: www.epid.coi.waw.pl $/ \mathrm{krn}$ [dostęp: 31.10.2016]

2. Siegel R.L., Miller K.D., Jemal A. Cancer statistics 2016. CA Cancer J. Clin. 2016; 66(1): 7-30, doi: 10.3322/caac.21332.

3. Felix A.S., Weissfeld J.L., Stone R.A., Bowser R., Chivukula M., Edwards R.P., Linkov F. Factors associated with Type I and Type II endometrial cancer. Cancer Causes Control. 2010; 21(11): 1851-1856, doi: 10.1007/s10552-0109612-8

4. Woodruff J.D., Pickar J.H. Incidence of endometrial hyperplasia in postmenopausal women taking conjugated estrogens (Premarin) with medroxyprogesterone acetate conjugated estrogens alone. The Menopause Study Group Am. J. Obstet. Gynecol. 1994; 170 (5 Pt1): 1213-1273, doi: 10.1016/s0002 9378(94)70129-6.

5. Alquobaili F., Miller S.A., Muhie S., Day A., Jett M., Hammamieh R. Estrogen receptor-dependent genomic expression profiles in breast cancer cells in response to fatty acids. J. Carcinog. 2010; 8: 17, doi: 10.4103/1477-3163.59539. 6. Kumar R., Zakharov M.N., Khan S.H., Miki R., Jang H., Toraldo G., Singh R., Bhasin S., Jasuja R. The dynamic structure of the estrogen receptor. J. Amino Acids 2011: 812540, doi: 10.4061/2011/812540.

7. Zielniok K., Gajewska M., Motyl T. Molekularne aspekty działania $17 \beta$-estradiolu i progesteronu w komórkowych szlakach sygnałowych. Postepy Hig. Med. Dosw. (online) 2014; 68: 777-792, doi: 10.5604/17322693.1108390. 8. Groenendijk F.H., Zwart W., Floore A., Akbari S., Bernards R. Estrogen receptor splice variants as a potential source of false-positive estrogen receptor status in breast cancer diagnostics. Breast Cancer Res. Treat. 2013; 140(3) 475-484, doi: 10.1007/s10549-013-2648-1.

9. Fujii-Kurijama Y., Mimura J. Molecular mechanism of AhR functions in the regulation of cytochrome P450 genes. Biochem. Biophys. Res. Commun. 2005 338(1): 311-317, doi: 10.1016/j.bbrc.2005.08.162.

10. Honkakoski P., Negishi M. Regulation of cytochrome P450 (CYP) genes by nuclear receptors. Biochem. J. 2000; 347(Pt2): 321-337.

11. Tomaszewski P., Kubiak-Tomaszewska G., Łukaszkiewicz J., Pachecka J. Cytochrome $\mathrm{P} 450$ polymorphism--molecular, metabolic, and pharmacogenetic aspects. Influence of CYP genetic polymorphism on population differentiation of drug metabolism phenotype. Acta Pol. Pharm. 2008; 65(3): 319-329.

12. Iwao K., Miyoshi Y., Egawa c., Ikeda N., Noguchi S. Quantitative analysis of estrogen receptor mRNA and its variants in human breast cancers. Int. J. Cancer 2000; 88: 733-736.

13. Whitehead M., Fraser D. The effects of estrogens and progestogens on the endometrium: modern approach to treatment. Obstet. Gynecol. Clin. North Am. 1987; 14(1): 299-302.

14. Licznerska B., Baer-Dubowska W. Estrogen intracrinology: therapy and chemoprevention of breast cancer. Postepy Hig. Med. Dosw. (online) 2010; 64: $220-230$.
15. Salama S.A., Kamel M., Awad M., Hakim A., Nasser B., Al-Hendy A., Botting $\mathrm{S}$. Catecholestrogens induce oxidative stress and malignant transformation in human endometrial glandular cells: protective effect of catechol-O-methyltransferase. Int. J. Cancer 2008; 123(6): 1246-1254, doi: 10.1002/ijc.23653. 16. Fuhrman B., Schairer C., Gail C., Boyd-Morin J., Xu X., Sue L.Y., Buys S.S., Isaacs C., Keefer L.K., Veenstra T.D., Berg C.D., Hoover R N , Ziegle R.G. Estrogen Metabolism and Risk of Breast Cancer in Postmenopausal Women. J. Natl. Cancer Inst. 2012; 104: 326-338, doi: 10.1093/jnci/djr531.

17. Hirata S., Yamada Mouri N., Nara M., Takazawa N., Ito H., Kato J. Presence of alternativeli spliced-estrogen receptor mRNA variants in normal human uterine endometrium and endometria cancer. Endoc. J. 1995; 42(2): 289-293, doi: 10.1507/endocrj.42.289.

18. Iwao K., Miyoshi Y., Egawa C., Ikeda N., Noguchi S. Quantitative analysis of estrogen receptor-beta mRNA and its variants in human brest cancer. Int. J. Cancer. 2000; 88(5): 733-736, doi: 10.1002/1097-0215(20001201)88:5<733::aid-ijc8>3.0.co;2-m.

19. Pettersson K., Gustafsson J.A. Role of estrogen receptor beta in estrogen action. Annu. Rev. Physiol. 2001; 63: 165-192, doi: 10.1146/annurev.physiol.63.1.165

20. Kato K., Houriochi S., Terao S., Ueoka Y., Nishida J., Mori D., Yoshikawa Y. Wake N. Relevance of ER to the development of endometrial hyperplasia and adenocarcinoma. Breast Cancer. 1999; 6(4): 312-319, doi: 10.1007/ bf02966446.

21. Witek A., Paul-Samojedny M., Stojko R., Seifert B., Mazurek U. Coexpression index of estrogen receptor alpha mRNA isoforms in simple, complex hyperplasia without atypia, complex atypical hyperplasia and adenocarcinoma Gynecologic Oncology 2007; 106(2): 407-412, 10.1016/j.ygyno.2007.04.035. 22. Al-Bader M., Ford C., Al-Ayadh B., Francis I. Analysis of estrogen receptor isoforms and variants in breast cancer cell lines. Exp. Ther. Med. 2011; 2(3): 537-544, doi: 10.3892/etm.2011.226.

23. Fujimoto J., Ichigo s., Hirose R., Sakaguchi H., Tamaya T. Expression of estrogen receptor wild type and exone 5 splicing variany mRNAs in normal and endometriotic endometria during the menstrual cycle. Gynecol. Endocrinol. 1997; 11(1): 11-16, doi: 10.3109/09513599709152310.

24. Lee M.T., Ho S.M., Tarapore P., Chung I., Leung Y.K. Estrogen Receptor $\beta$ Isoform 5 Confers Sensitivity of Breast Cancer Cell Lines to Chemotherapeutic Agent-Induced Apoptosis through Interaction with Bcl2L12. Neoplasia. 2013; 15(11): 1262-1271, doi: 10.1593/neo.131184.

25. Chi A., Chen C., Chirala M., Younes M. Differential expression of estrogen receptor beta isoforms in human breast cancer tissue. Anticancer Res. 2003; 23 (1A): 211-216.

26. Zhou S. Human CYP39A1, 46A1, and 51A1. In: Zhou S. Cytochrome P450 2D6: Structure, Function, Regulation and Polymorphism. CRC Press Taylor \& Francis Group 2016, Boca Raton 59. 